\title{
Cranial Morphometrics of a Stranded Common Bottlenose Dolphin Tursiops truncatus (Montagu, 1821) in Mersin Bay (Northeastern Mediterranean, Turkey)
}

Deniz Ayas

Faculty of Fisheries, Mersin University Yenişehir Campus, 33160, Mersin, Turkey. E-mail: ayasdeniz@mersin.edu.tr

Deniz Ergüden (Corresponding Author)

Department of Marine Sciences, Faculty of Marine Sciences and Technology, Iskenderun Technical University, TR 31220, Iskenderun, Hatay, Turkey.

E-mail: deniz.erguden@iste.edu.tr

Nuray Çiftci

Faculty of Fisheries, Mersin University Yenişehir Campus, 33160, Mersin, Turkey.

E-mail: nciftci@mersin.edu.tr

Mustafa Doğangün

Faculty of Fisheries, Mersin University Yenişehir Campus, 33160, Mersin, Turkey. E-mail: mustafadogangun23z@gmail.com

Hasan Deniz Akbora

Department of Biological Sciences, Faculty of Arts and Sciences, Eastern Mediterranean University, Famagusta 99628, North Cyprus via Mersin 10, Turkey.

E-mail: hasan.deniz@emu.edu.tr

\section{Misra Bakan}

Faculty of Fisheries, Mersin University Yenişehir Campus, 33160, Mersin, Turkey. E-mail:misrabakann@gmail.com 
Received: Dec. 4, 2019 Accepted: Feb. 10, 2020 Published: Feb. 26, 2020

doi:10.5296/ast.v8i1.16124

URL: https://doi.org/10.5296/ast.v8i1.16124

\begin{abstract}
On 10 November 2017, a young male common bottlenose dolphin Tursiops truncatus (Montagu, 1821), $185 \mathrm{~cm}$ in total length (TL), was found dead on the Mersin Marina $\left(36^{\circ} 46^{\prime} 065^{\prime \prime} \mathrm{N}, 34^{\circ} 34^{\prime} 212^{\prime \prime} \mathrm{E}\right)$ in Northeastern Mediterranean coast of Turkey. Measurements of the sample performed and documented. The specimen buried to obtain the skeleton of the individual. At the end of this process, the sample was deposited in the Museum of the Systematic, Faculty of Fisheries, Mersin University, (Catalogue no: MEUMC-17- 11-001). The morphometric measurements can contribute to ongoing fisheries biology and taxonomic studies of T. truncatus from Mediterranean Sea waters. During routine fishing activities, common bottlenose dolphins can be caught in fishing nets and drowned. This issue leads to an extra population loss in addition to environmental factors that cause dolphin deaths. At the national level, measures should be implemented to protect dolphins and other marine species caught off -target.
\end{abstract}

Keywords: Common bottlenose dolphin, Tursiops truncatus, human effect, Mediterranean Sea, Turkey

\title{
1. Introduction
}

Common bottlenose dolphins Tursiops truncatus (Montagu, 1821) belonging to the Delphinidae family, are widely accepted in the Mediterranean Sea (Pilleri \& Gihr, 1969; Cagnolaro et al., 1983; Notarbartolo di Sciara \& Demma, 1994; Bearzi \& Fortuna, 2006).

Tursiops truncatus is gray, and the abdomen is lighter in color. Its dark-colored sickle-shaped dorsal fin can quickly identify $T$. truncatus. No other bottle-nosed dolphin ecotype has been identified so far in the Mediterranean. Notarbartolo di Sciara \& Demma (1994) stated that the Mediterranean population of T. truncatus is more related to the coastal ecotype due to the shallow water habits.

Tursiops truncatus prefer shallow waters as habitats. This preference may be related to the feeding habits of the species that feeding mostly on benthic and demersal fish (Voliani \& Volpi, 1990; Orsi Relini et al., 1994; Silva \& Sequeira, 1997; Mioković et al., 1999; Blanco et al., 2001; Santos et al., 2001).

There are different opinions among the researchers as to whether T. truncatus belonging to the genus Tursiops should be divided into a single species or several species. Some authors stated that it should be divided into Atlantic bottlenose (T. truncatus), Indopacific bottlenose ( $T$. aduncus) and Pacific bottlenose (T. gillii). Recently, this distinction has not been generally accepted. Rice (1998) stated that T. aduncus is a separate species, but $T$. gillii is only a subspecies of T. truncatus. 
Also, according to various researcher's studies', it is stated that the bottlenose dolphin found in the Black Sea is a subspecies of the bottlenose dolphin of the Atlantic and should be called Tursiops truncatus ponticus (Ridgway \& Harrisson, 1999; Reynolds III et al., 2000; Reeves et al., 2002; Reynolds, III \& Wells, 2003; Jefferson et al., 2008).

T. truncatus live in small groups, and each group has a mature male, the rest of the group consists of female and offspring. They communicate with each other with high-frequency sounds. Each dolphin has a unique voice (name) that identifies its identity and also uses it while hunting (Janik et al., 1994). Their total length varies between 190-400 cm, and they can reach weights up to $650 \mathrm{~kg}$ (Sergeant, 1969). The pregnancy period in dolphins is one year. At birth, their tails go out first, so they do not have the risk of suffocation at birth, which can last up to 2 hours. Immediately after birth, the mother pushes her offspring towards the water surface and allows it to breathe for the first time. Newborn babies are of 65 to $105 \mathrm{~cm}$ total length and 15$30 \mathrm{~kg}$ in weight. T. truncatus can live up to the age of 25 , but some have reached the age of 35 under captivity (Shirihai et al., 2006).

In this study, morphometric measurements of T. truncatus, which were accidentally caught in the fishing net and stranded in Mersin Marina, were taken and compared with previous studies. The data obtained are aimed to contribute to the researchers engaged in fisheries biology and taxonomic studies. Information on the causes of deaths for this species and some recommendations for protection also has given.

\section{Material and Methods}

\subsection{Study Site}

In this study, a bottlenose dolphin was recorded near the Mersin Marina (Mersin Bay, Turkey), (Figure 1). Mersin coast is an enclosed system and has oligotrophic water; its biodiversity is continually changing with fish's migration. The Mersin Bay is an important fishing area of the Northeastern Mediterranean Sea due to the nutrient-rich freshwater inputs. The muddy, sandy seabed and the productive environment provide suitable living bio-habitats for all sea creatures.

\subsection{Sampling}

On 10 November 2017, a young male bottlenose dolphin T. truncatus, $185 \mathrm{~cm}$ in total length (TL), was found dead on the Mersin Marina (36 $\left.{ }^{\circ} 46^{\prime} 065^{\prime \prime} \mathrm{N}, 34^{\circ} 34^{\prime} 212^{\prime \prime} \mathrm{E}\right)$ in Northeastern Mediterranean coast of Turkey (Figure 1). The specimen of the bottlenose dolphin buried to obtain the skeleton of the individual. Once the skeleton is obtained, the sample was deposited in the Museum of the Systematic, Faculty of Fisheries, Mersin University, (Catalogue No: MEUMC-17-11-001). The sampling location of the species in the Mediterranean Sea presented in Figure 1. Photographs of the caught sample shown in Figure 2 and the skeleton specimen of T. truncatus given in Figure 3. 


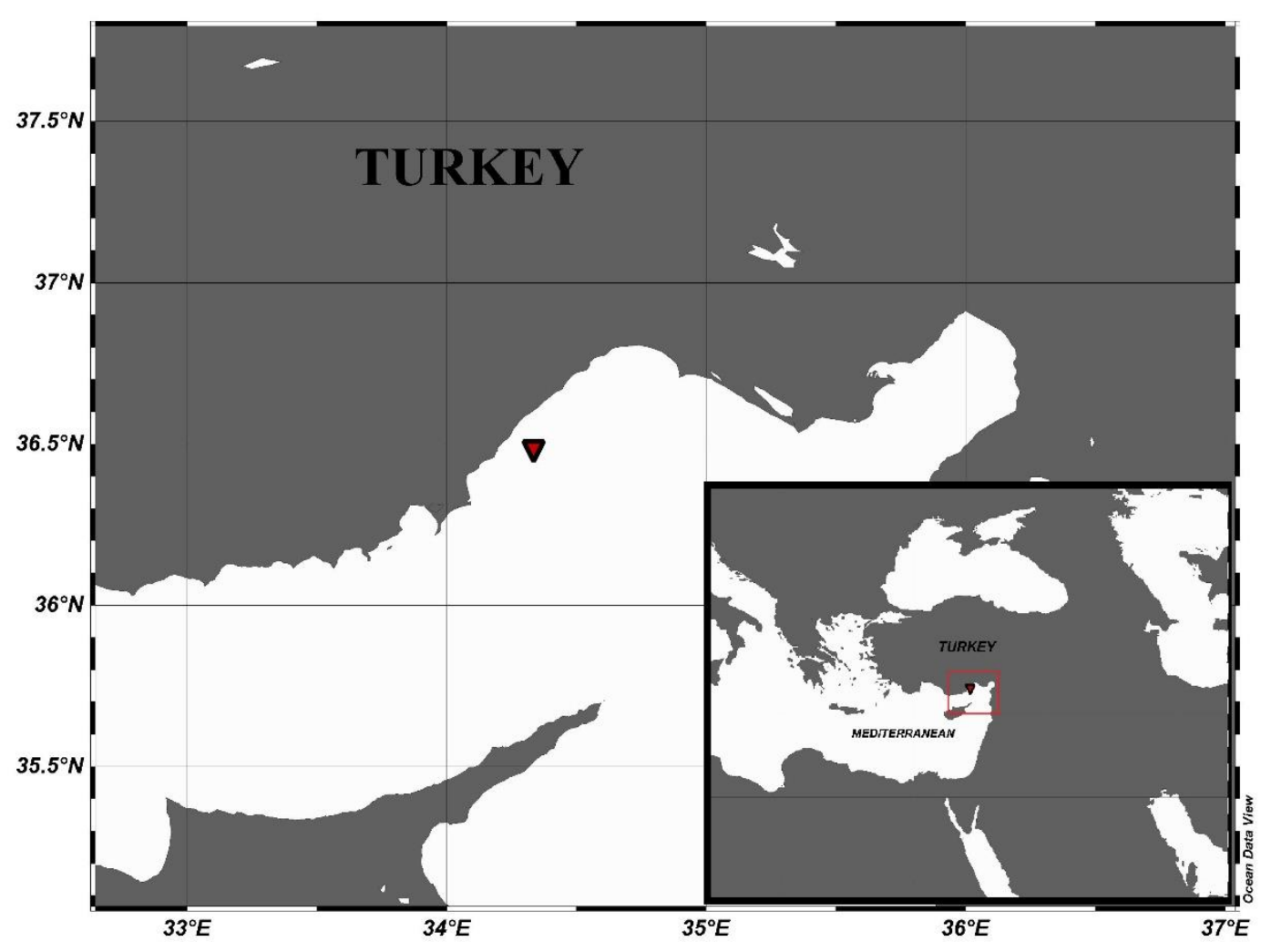

Figure 1. The red mark indicates the location where the specimen found

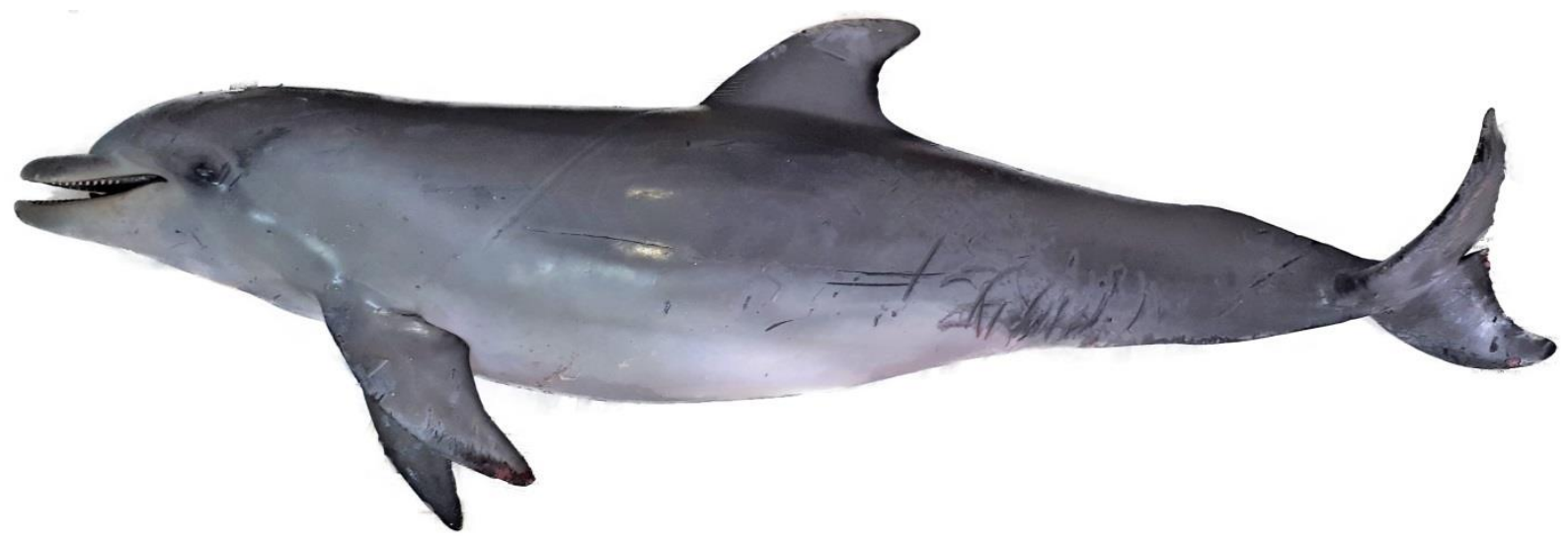

Figure 2. The specimen of T. truncatus from Mersin Bay 


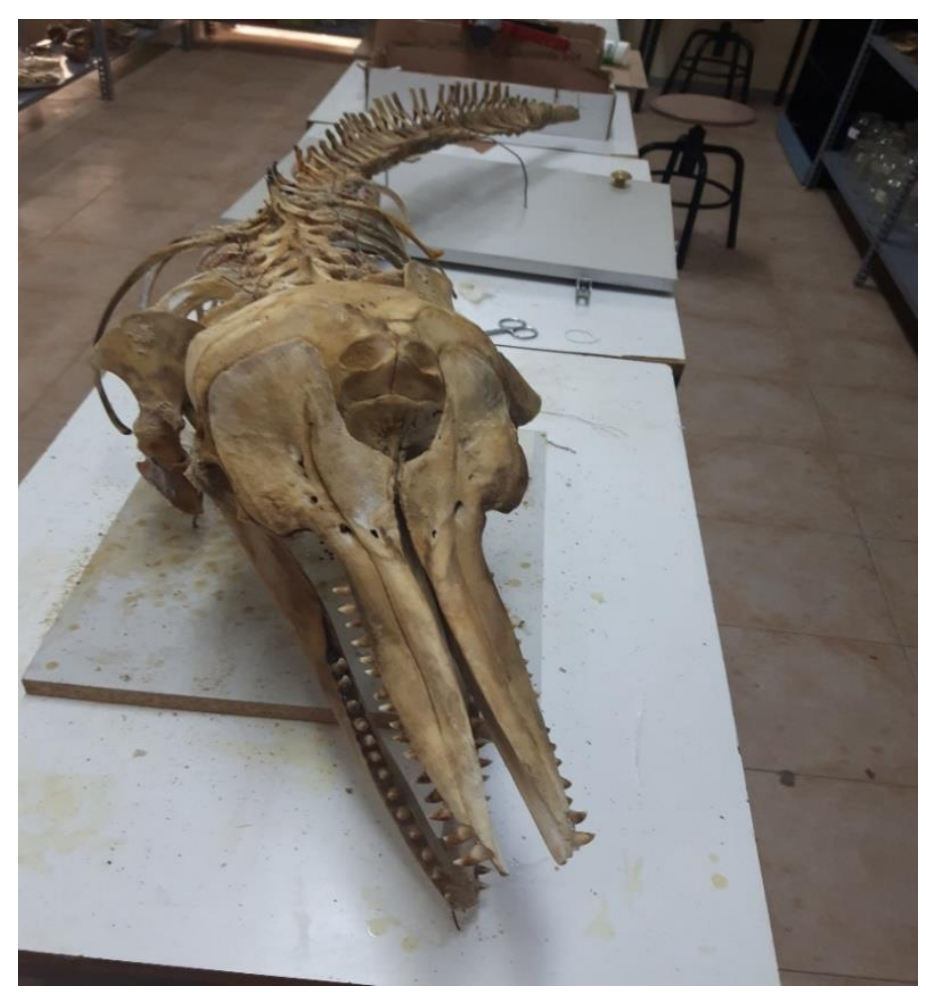

Figure 3. The skeleton of $T$. truncatus

\section{Results}

The T. truncatus individual, identified as male, is gray, and the abdomen is lighter in color. The dorsal fin is dark-colored and sickle-shaped. The sample had a $185 \mathrm{~cm}$ total length. The fins and front extremities had some hemorrhage and injuries. Also, there were some deep rope incisions on the body. In the study, cranial morphological data of the head of T. truncatus specimen were examined comparatively with the stranded samples on the shores of China Sea (Wang et al., 2000) and South Africa (Ross, 1977, 1984) (Table 1). Some morphometrics measured in this study are the following: Mandibular height (MH) is $63.2 \mathrm{~mm}$, the upper teeth row length (UTRL) value is $157.4 \mathrm{~mm}$, and the mandibular length (ML) value is $286.5 \mathrm{~mm}$. Preorbital width (PRQ) and postorbital width (POW) values are $116.3 \mathrm{~mm}$ and $112.9 \mathrm{~mm}$. Condylobasal length (CBL) and inter-supraorbital width (SOW) values measured as 385.5 and 142.4, respectively (Table 1 ). 
Table 1. Comparison of cranial data of T. truncatus specimen with previous studies

\begin{tabular}{|c|c|c|c|}
\hline Character (mm) & $\begin{array}{c}\text { Mersin } \\
\text { This study }\end{array}$ & $\begin{array}{c}\text { China (min/max) } \\
\text { Wang et al. (2000) }\end{array}$ & $\begin{array}{c}\text { South Africa } \\
(\mathrm{min} / \mathrm{max})\end{array}$ \\
\hline $\begin{array}{l}\text { Number of sample } \\
\text { (n) }\end{array}$ & 1 & 2 & 2 \\
\hline $\mathrm{MH}$ & 63.2 & $61.0-104.4$ & $90.1-109.8$ \\
\hline MFL & 42.1 & - & - \\
\hline ML & 286.5 & $340.8-480.8$ & $425.8-498.2$ \\
\hline RW & 82.9 & - & - \\
\hline RL & 192.5 & 203.5-319.6 & $183.2-334.6$ \\
\hline ONW & 51.8 & - & - \\
\hline UTRL & 157.4 & $172.0-277-7$ & $154.0-276.9$ \\
\hline LTRL & 156.0 & - & - \\
\hline ONRL & 263.1 & $243.5-375.2$ & $337.2-386.9$ \\
\hline $\mathrm{OL}$ & 42.7 & - & - \\
\hline RPW & 66.3 & - & - \\
\hline TDMM & 7.3 & - & - \\
\hline TDMR & 7.1 & - & - \\
\hline TFW & 158.3 & - & - \\
\hline POW & 116.3 & $171.5-262.5$ & $229.8-276.9$ \\
\hline $\mathrm{ZW}$ & 154.4 & - & - \\
\hline $\mathrm{CBL}$ & 385.5 & $394.4-561.1$ & $450.7-529.1$ \\
\hline SOW & 142.4 & $163.2-254.1$ & $228.8-269.8$ \\
\hline POW & 112.9 & $187.2-286.6$ & 253.9-301.1 \\
\hline
\end{tabular}

MFL: Mandibular Fossa Length, ML: Mandibular Length. RW: Width of rostrum. RL: Rostrum length, ONW: Outer Nose Width, UTRL: Upper Tooth Row Length, LTRL: Lower Tooth Row Length, OL: Orbital Length, ONRL: Length from Outer Nostrils to Rostrum End, RPW: Rostrum Width in Rostrum Pre-maxillary, TDMM: Tooth Diameter in the Middle of Mandibul, TDMR: Tooth Diameter in the Middle of Rostrum, TFW: Posterior Boundary Width of Temporal Fossa, POW: Width between Pre-orbitals, PRW: Width Between Pre-orbitals, ZW: Skull Zigomatic Width, CBL: Condylobasal Length, SOW: Supraorbitals Width.

The ratio of skull measurements of T. truncatus specimens stranded in Gökçeada and Mersin Bay to condylobasal length is given in Table 2. 
Table 2. Skull measurements ratios of T. truncatus to CBL (mm)

\begin{tabular}{ccc}
\hline Character & $\begin{array}{c}\text { Çanakkale/Gökçeada } \\
\text { Doğangün (2018) }\end{array}$ & $\begin{array}{c}\text { Mersin (Mediterranean) } \\
\text { This study }\end{array}$ \\
CBL/CBL & 1 & 1 \\
MH/CBL & 0.190 & 0.163 \\
MFL/CBL & 0.274 & 0.109 \\
UTRL/CBL & 0.500 & 0.408 \\
RPW/CBL & 0.245 & 0.301 \\
POW/CBL & 0.505 & 0.298 \\
LTRL/CBL & 0.463 & 0.404 \\
DDRU/CBL & 0.693 & 0.682 \\
PRW/CBL & 0.447 & 0.301 \\
ZW/CBL & 0.516 & 0.400 \\
OL/CBL & 0.151 & 0.110 \\
RL/CBL & 0.596 & 0.499 \\
SOW/CBL & 0.556 & 0.369 \\
ML/CBL & 0.858 & 0.743 \\
\hline
\end{tabular}

The rostral measurement of $T$. truncatus specimens stranded in Gökçeada and Mersin Bay are given in Table 3 in detail. The ratio of rostral measurement data to zygomatic width (RL / ZW) was found to be 1.247 in Mersin sample (Table 3).

Table 3. Rostral measurement ratios of T. truncatus specimen (mm)

\begin{tabular}{ccc}
\hline Character & $\begin{array}{c}\text { Çanakkale/Gökçeada } \\
\text { Doğangün (2018) }\end{array}$ & $\begin{array}{c}\text { Mersin (Mediterranean) } \\
\text { This study }\end{array}$ \\
\hline RL/ZW & 1.155 & 1.247 \\
RL/CBL & 0.598 & 0.499 \\
RPW/ZW & 0.475 & 0.431 \\
RPW/RL & 0.411 & 0.343 \\
\hline
\end{tabular}

Mandibular measurement ratios $(\mathrm{mm})$ of the T. truncatus specimens are given in Table 4 for Gökçeada and Mersin samples. 
Table 4. Mandibular measurement ratios of T. truncatus specimen (mm)

\begin{tabular}{ccc}
\hline Character & $\begin{array}{c}\text { Çanakkale/Gökçeada } \\
\text { Doğangün (2018) }\end{array}$ & $\begin{array}{c}\text { Mersin (Mediterranean) } \\
\text { This study }\end{array}$ \\
\hline ML/CBL & 0.914 & 0.743 \\
LTRL/ML & 0.516 & 0.544 \\
MFL/ML & 0.295 & 0.146 \\
MH/ML & 0.165 & 0.220 \\
\hline
\end{tabular}

The postcranial numbers of $T$. truncatus specimens are given in Table 5. The first two vertebrae fused in the cervical region.

Table 5. Postcranial numbers of T. truncatus

\begin{tabular}{ccc}
\hline Character & $\begin{array}{c}\text { Çanakkale/Gökçeada } \\
\text { Doğangün (2018) }\end{array}$ & $\begin{array}{c}\text { Mersin (Mediterranean) } \\
\text { This study }\end{array}$ \\
\hline Cervical & 7 & 7 \\
Thoracic & 13 & 13 \\
Lumbar & 15 & 15 \\
Caudal & 26 & 21 \\
Total & 61 & 56 \\
\hline
\end{tabular}

\section{Discussion}

The Mandibular height $(\mathrm{MH})$ value $(63.2 \mathrm{~mm})$ of the Mersin specimen of T. truncatus was closely similar to the Chinese sample, which was smaller than the other one $(61.0 \mathrm{~mm})$ (Wang et al., 2000). Rostrum length (RL) value $(192.5 \mathrm{~mm})$ is quite different from an individual of (smaller one) the South Africa sample (183.2 mm) (Ross, 1977). Table 1 shows that the UTRL value is similar to the South African samples (smaller one), and the ONRL value is similar to the smaller individual of Chinese samples. When the mandibular length (ML) value is examined, it is seen that this value is higher in China (340.8 - $480.8 \mathrm{~mm}$ ) and South African samples $(425.8$ - $498.2 \mathrm{~mm})$ in Mersin sample $(286.5 \mathrm{~mm})$. When the values between preorbitals width (PRW) and postorbital width (POW) were examined, it was found that these values in the Mersin sample were quite smaller (116.3 - $112.9 \mathrm{~mm})$ than China (171.5 - 187.2 $\mathrm{mm}$ ) and South Africa (229.8 - $253.9 \mathrm{~mm})$. Also, condylobasal length (CBL) and intersupraorbital width (SOW) values are slightly lower than the comparable samples.

The stranded of T. truncatus specimens of the skull measurements were compared with studies in Aegean (Gökçeada) and Mediterranean (Mersin) regions; RPW / CBL ratio was found to be greater in the sample in Mediterranean region, and other measurements were smaller (Table 2). In the rostral measurement values, it was found that the RL / ZW ratio was high, and the other data were low in the species belonging to the Mediterranean region (Table 3). Table 4 shows 
that the LTRL / ML data are similar in both samples, and the MH / ML ratio is high in the Mediterranean region. In the postcranial data of T. truncatus specimens, there is no significant difference between the vertebrae of the skeleton (Table 5). The first two vertebrae are fused in the cervical region, which is a characteristic of dolphins. Thoracic and Lumbar regions are equal in spine numbers. However, an excess of spine detected in the Caudal region in the Çanakkale/Gökçeada sample. Rommel (1990), in his study on T. truncatus, the maximum and minimum values of the number of vertebrae were determined as 60-65. As a result, there may be various regional differences between individuals of the same species.

Reeves \& Notarbartolo di Sciara (2006) evaluated the status of bottlenose dolphins in the Mediterranean within the scope of a regional Red List Workshop held in March 2006, and they have stated that this species had a bottleneck in the Mediterranean Sea and could be considered as a sub-population.

Bearzi \& Fortuna (2006), under the IUCN red list the criteria that are the main reasons for the decrease in the number of $T$. truncatus. They stated that there are threats from overfishing of the populations, habitat degradation, chemical pollutants, and environmental pollution.

According to Perrin \& Geraci (2009), a live Cetacean species can land again when returned to the sea. However, they may decide that they cannot survive or float at sea, but may also land on the sea to continue breathing. Valuable information about anatomy, life history, genetics, diseases, parasites, predators, and nutritional ecologies of marine mammals can be obtained from carcasses stranded. Each stranding event can be considered as a potential opportunity that cannot be learned otherwise.

Today, although the exact cause of mass stranding is not known, marine mammals are stranded by the effects of wave and wind as dead or fallen due to many natural or unnatural reasons (Wayne, 1984). Reasons for mass hitting; epidemics and parasites, biotoxins, acoustic dead zones, changes in world magnetism, significant climatic changes, seasonal changes in environmental conditions. Besides, due to the decrease in food resources, hunger, sun-bursting activities can be due to reasons such as human-caused reasons (Geraci \& Lounsbury, 2005).

According to various researchers (Fernández et al., 2005; Perrin \& Geraci, 2009), seismic investigations during oil exploration and extraction, organochlorine compounds, which cause increased viral outbreaks in marine mammals can lead to death by weakening the immune system. Besides, military sonars have also been shown to cause mass deaths of dolphins (Perrin \& Geraci, 2009).

The specimen found in this study had a lot of injuries on the fins and the body. With a detailed examination of the body of the sample, it can be thought that an incidental catch was the cause of death. Although fishing activities do not target dolphins in the Mediterranean. In the present study, the bottlenose dolphin individual in the Mersin Marina found dead as incidentally in fishing nets. Thus, this situation should not be ignored in bottlenose dolphin deaths in the Eastern Mediterranean. 


\section{Conclusion}

The bottlenose dolphin individual recovered from the eastern Mediterranean waters once again demonstrates the destructive effects of the fishing activity on the dolphins in this region. The bottlenose dolphin individual in the Mersin Bay drowned as a result of accidental fishing. This result is thought to be an essential factor in bottlenose dolphin deaths in the Eastern Mediterranean. Therefore, it is considered necessary to increase the local and national protection measures for these species in our country and the Mediterranean.

\section{Acknowledgment}

This study was supported by the Research Fund of Mersin University in Turkey with Project Number: 2017-2-AP2-2353.

\section{References}

Bearzi, G., \& Fortuna, C. M. (2006). Common bottlenose dolphin Tursiops truncatus (Mediterranean subpopulation). In R. R. Reeves, \& G. Notarbartolo di Sciara (Eds.), The status and distribution of cetaceans in the Black Sea and Mediterranean Sea (pp. 64-73). IUCN Centre for Mediterranean Cooperation, Malaga, Spain.

Bell, C. H., Kemper, C. M., \& Conran, J. G. (2002). Common dolphins Delphinus delphis in southern Australia: A morphometric study. Australian Mammalogy, 24, 1-10. https://doi.org/10.1071/AM02001

Blanco, C., Salomón, O., \& Raga, J. A. (2001). Diet of the bottlenose dolphin (Tursiops truncatus) in the western Mediterranean Sea. Journal of the Marine Biological Association of the United Kingdom, 81, 1053-1058. https://doi.org/10.1017/S0025315401005057

Cagnolaro L, Di Natale A., \& Notarbartolo di Sciara G. (1983). Cetaceans. Guides for the recognition of animal species of Italian lagoon and coastal waters. AQ / 1/224, 9. Consiglio Nazionale delle Ricerche: Genova, Italy. p. 183.

Doğangün, M. (2018). Comparative osteological examination of Tursiops truncatus and Delphinus delphis species. Çanakkale 18 March University, Gökçeada School of Applied Sciences Department of Fisheries Technologies, Msc Thesis, pp: 18-20. (in Turkish)

Fernández, A., Edwards, J. F., Rodriguez, F., Espinosa De Los Monteros, A., Herraez, P., Castro, P., Jaber, J. R., Martin, V., \& Arbelo, M. (2005). Gas and fat embolic syndrome involving a mass stranding of beaked whales (family Ziphiidae) exposed to anthropogenic sonar signals. Veterinary Pathology, 42, 446-457. https://doi.org/10.1354/vp.42-4-446

Geraci, R. J., \& Lounsbury, J. V. (2005). Marine Mammals Ashore, A Field Guide for Strandings. 2. Edition. National Aquarium, in Baltimore, Inc, U.S.A.

Janik, V. M., Todt, D., \& Dehnhardt, G. (1994). Signature whistle variations in a bottlenosed dolphin, Tursiops truncatus. Behavioral Ecology and Sociobiology, 35, 243-248. https://doi.org/10.1007/BF00170704

Jefferson, T., Webber, M., \& Pitman, R. (2008). Marine Mammals of the World. Burlington, 
MA: Academic Press. p. 616.

Mioković, D., Kovačić, D., \& Pribanić, S. (1999). Analysis of stomach contents of a bottlenosed dolphin (Tursiops truncatus, Montagu 1821) from the Adriatic Sea. Natura Croatica, 8, 61-65.

Notarbartolo di Sciara G., \& Demma M. (1994). Guida dei Mammiferi Marini del Mediterraneo. Franco Muzzio Editore: Padova, Italy.

Orsi Relini, L, Capello, M., \& Poggi, R. (1994). The stomach content of some bottlenose dolphins (Tursiops truncatus) from the Ligurian Sea. European Research on Cetaceans, 8, 192-195.

Perrin, F. W., \& Geraci, R. J. (2009). Stranding. In W. F. Perrin, B. Würsig, \& J. G. M. Thewissen, (Eds.), Encyclopedia of Marine Mammals (pp 1118-1123). Second Edition. USA: Academic Press. https://doi.org/10.1016/B978-0-12-373553-9.00256-X

Pilleri, G., \& Gihr, M. (1969). Uber adriatische Tursiops truncates (Montagu, 1821) und vergleichende Untersuchungen über mediterrane und atlantische Tümmler. Investigations on Cetaceans, 1, 66-73.

Reeves, R., \& Notarbartolo di Sciara, G. (2006). The Status and Distribution of Cetaceans in the Black Sea and Mediterranean Sea. IUCN Centre for Mediterranean Cooperation, Málaga, Spain. p. 137.

Reeves, R., Stewart, B., Clapham, P., \& Powell. J. (2002). Sea Animals of the World. New York: A \& C Black Publishers.

Reynolds, III, J., \& Wells, R. (2003). Dolphins, Whales, and Manatees. Gainesville, Florida: University Press of Florida.

Reynolds, III, J., Wells, R., \& Eide, S. (2000). Bottlenosed Dolphin. Gainesville, Florida: University Press of Florida.

Rice, D. W. (1998). Marine Mammals of the World: Systematics and distribution. Special Publication. 4: The Society for Marine Mammalogy. p. 231.

Ridgway, S., \& Harrison. S. (1999). Handbook of Marine Mammals. London: Academic Press.

Rommel, S. (1990). Osteology of the bottlenose dolphin. In S. Leatherwood, \& R. R. Reeves, (Eds.), The bottlenose dolphin (pp. 29-49). Academic Press, San Diego. https://doi.org/10.1016/B978-0-12-440280-5.50006-8

Rommel, S. 1990. Osteology of the bottlenose dolphin. In S. Leatherwood, \& R. R. Reeves (Eds.), The bottlenose dolphin (pp 29-49). San Diego: Academic Press. https://doi.org/10.1016/B978-0-12-440280-5.50006-8

Ross G. J. B. (1977). The taxonomy of bottlenosed dolphins Tursiops in South African waters, with notes on their biology. Annals of the Cape Provincial Museums (Natural History), 11, 135-194. 
Ross G. J. B. (1984). The smaller cetaceans of the South east coast of southern Africa. Annals of the Cape Provincial Museums (Natural History), 15, 173-410.

Santos, M. B., Pierce, G. J., Reid, R. J., Patterson, I. A. P., Ross, H. M., \& Mente, E. (2001). Stomach contents of bottlenose dolphins (Tursiops truncatus) in Scottish waters. Journal of the Marine Biological Association of the United Kingdom, 81, 873-878. https://doi.org/10.1017/S0025315401004714

Sergeant, D. E. (1969). Feeding rates of Cetacea. Fisk Dir. Skr. Ser.Hav Unders. 15, 246-258.

Shirihai, H., Jarrett, B., \& Kirwan, G. M. (2006). Whales, dolphins, and other marine mammals of the world. Princeton: Princeton University Press.

Silva, M.A., \& Sequeira, M. (1997). The stomach content of marine mammals in the Portuguese coast. European Research on Cetaceans, 11, 176-179.

Voliani A, \& Volpi C. (1990). Stomach content analysis of Tursiops truncatus. Rapport du Congrès de la Commission International. Scientific de la Mer Méditerranée, 32.

Wang, J. Y., Chou, L. S., \& White, B. N. (2000). Osteological differences between two sympatric forms of bottlenose dolphins (genus Tursiops) in Chinese waters. Journal of Zoology, 252, 147-162. https://doi.org/10.1111/j.1469-7998.2000.tb00611.x

Wayne, P. S. (1984). The role of disturbance in natural communities. Annual Review of Ecology and Systematics Department of Zoology, University of California, 15, 353-391. https://doi.org/10.1146/annurev.es.15.110184.002033

\section{Copyrights}

Copyright for this article is retained by the author(s), with first publication rights granted to the journal.

This is an open-access article distributed under the terms and conditions of the Creative Commons Attribution license (http://creativecommons.org/licenses/by/4.0/) 